\title{
Evaluation of Streptomyces saraciticas as Soil Amendments for Controlling Soil-Borne Plant Pathogens
}

\author{
Pei-Hsuan Wu', Tung-Tsuan Tsay', and Peichen Chen (iD ${ }^{2 *}$ \\ ${ }^{I}$ Taiwan Agricultural Chemicals and Toxic Substances Research Institute, Council of Agriculture, Executive Yuan, \\ Taichung 413001, Taiwan \\ ${ }^{2}$ Department of Plant Pathology, National Chung Hsing University, Taichung 40227, Taiwan
}

(Received on August 22, 2021; Revised on October 3, 2021; Accepted on October 24, 2021)

Soil-borne diseases are the major problems in mono cropping. A mixture (designated LTM-m) composed of agricultural wastes and a beneficial microorganism Streptomyces saraceticus SS31 was used as soil amendments to evaluate its efficacy for managing Rhizoctonia solani and root knot nematode (Meloidogyne incognita). In vitro antagonistic assays revealed that SS31 spore suspensions and culture broths effectively suppressed the growth of $R$. solani, reduced nematode egg hatching, and increased juvenile mortality. Assays using two Petri dishes revealed that LTM-m produced volatile compounds to inhibit the growth of $R$. solani and cause mortality to the root knot nematode eggs and juveniles. Pot and greenhouse tests showed that application of $0.08 \%$ LTM-m could achieve a great reduction of both diseases and significantly increase plant fresh weight. Greenhouse trials revealed that application of LTMm could change soil properties, including soil $\mathrm{pH}$ value, electric conductivity, and soil organic matter. Our results indicate that application of LTM-m bio-organic amendments could effectively manage soil-borne pathogens.

\section{*Corresponding author.}

Phone) +886-4-22840780-377, FAX) +886-4-22876712

E-mail) janetchen@nchu.edu.tw

ORCID

Peichen Chen

http://orcid.org/0000-0001-6905-7257

Handling Editor : Mee Kyung Sang

(c) This is an Open Access article distributed under the terms of the Creative Commons Attribution Non-Commercial License (http:// creativecommons.org/licenses/by-nc/4.0) which permits unrestricted noncommercial use, distribution, and reproduction in any medium, provided the original work is properly cited.

Articles can be freely viewed online at www.ppjonline.org.
Keywords : bio-organic amendment, Meloidogyne incognita, organic farming, Rhizoctonia solani, soil property

Organic vegetables have become increasingly popular worldwide because of the issue and concern in food safety and environmental problems resulting from excessive uses of toxic chemicals. To control plant diseases in organic farming, development of biological control measures using beneficial microorganisms is a promising alternative. Most of the managing strategies in organic agriculture rely on physical and biological controls, which have achieved some success on controlling foliar diseases. However, biological control has limited success on controlling soilborne plant parasitic pathogens, which are often the main obstacles for the production in organic farms (Huang et al., 2013). To combat soil-borne pathogens in organic farming, application of organic soil amendments can be beneficial and cost-effective.

Organic soil amendments using agricultural products or wastes have been known to improve soil chemical and physical properties, enrich beneficial organisms in soil environments, increase enzymatic activity, and elevate the rate of decomposition (Goyal et al., 1999). Recycling agricultural wastes can reduce production cost and benefit environmental conservation (Al-Barakah et al., 2013). Many agricultural wastes such as chitinous materials (shrimp and crab shell powder), oil cakes, and plant residues have been used to control plant diseases (Bonanomi et al., 2007; Sikora and Roberts, 2018). Chitinous materials have been shown to enrich the population of chitinolytic microorganisms. Chitinase produced by chitinolytic microorganisms has been known to be vital for controlling soil-borne pathogens because it can break down fungal cell wall and nematode egg shells (Oka, 2010). Thus, agricultural wastes are 
often used as soil amendments to elevate the population of chitinolytic microorganisms.

Many Streptomyces spp. can produce antibiotics and chitinases (Tang-um and Niamsup, 2012). Others have hyperparasitic abilities on fungal pathogens (Prabavathy et al., 2006; Sutherland and Papavizas, 1991; Zuberer et al., 1988). Many Streptomyces spp. collected in our lab have been shown to inhibit different pathogens. Streptomyces saraciticas SS31 originally isolated from a citrus grove has been proven to inhibit a number of plant pathogens, including Pytihum aphanidermatum, Rhizoctonia solani AG4 HGII, Sclerotium rolfsii, Fusarium solani Vn4-2, Alternaria brassicicola, Xanthomonas axonopodis pv. vesicatoria, $X$. vesicatoria, $X$. axonopodis subsp. citri, X. campestris pv. campestris, Acidovorax avenae subsp. citrulli, and Pectobacterium carotovorum subsp. carotovorum (Chen, 2008; Huang, 2016). The SS31 strain is capable of promoting plant growth and producing indoleacetic acid, siderophore, and hydrolytic enzymes such as amylase, protease, cellulase, and chitinase ( $\mathrm{Tu}, 2014)$.

In 2019, an organic farm in Kaohsiung, Taiwan, reported severe yield losses due to several soil-borne diseases caused by Rhizoctonia damping off, club root disease of Brassicaceae, bacterial soft rot and root knot nematode (Meloidogyne incognita). Of them, Rhizoctonia damping off and $M$. incognita are the most commonly identified problems in the region. In this study, S. saraciticas SS31 was mixed with several agricultural products or wastes, including soybean meal, crab and shrimp shells, neem seed oilcake, sugar, and dolomite to form a bio-organic soil amendment designated LTM-m. Pot and greenhouse trials were carried out to evaluate the efficacy of LTM-m for controlling $R$. solani and M. incognita. LTM-m produced toxic metabolites and volatile compounds, both of which could suppress the growth of $R$. solani and reduce damping-off. Application of LTM-m also effectively suppressed egg hatching and the formation of root knot. Nematode eggs after being treated with LTM-m became deformed or lysed. Overall, our results have shown that a combination of SS31 and agricultural products is effective in controlling soil-borne plant pathogens. This present study provides an example of how to utilize eco-friendly natural products and microorganisms as a soil amendment for disease management in organic agriculture.

\section{Materials and Methods}

Identification and maintenance of microorganisms. Two soil-borne pathogens: $R$. solani and root knot nematode (RKN) M. incognita were collected from diseased plants in Yonglin organic farm (Kaohsiung, Taiwan). $R$. solani was isolated from okra (Abelmoschus esculentus) and M. incognita was from spoon cabbage (Brassica chinensis L. cv. Ching-Geeng). $R$. solani was cultured on potato dextrose agar (PDA) at $28^{\circ} \mathrm{C}$ for 4 days and stored in $10 \%$ soil mixed with $1 \%$ agar. $M$. incognita was maintained on water spinach for 30 days. Nematode eggs were harvested and washed by $\mathrm{NaOCl}$ according to Hussey (1973). Fungal DNA was extracted using Tissue \& Cell Genomic DNA Purification Kit (GeneMark, Taipei, Taiwan). $R$. solani was identified to the species by sequence similarity of a DNA fragment amplified by PCR using two primers V9G (5'-TTACGTCCCTGCCCTTTGTA-3') (van den Ende and de Hoog, 1999) and ITS4 (5'-TCCTCCGCTTATTGATATGC-3') (Al-Fadhal et al., 2018; Damm et al., 2019). Nematode DNA was extracted using Direct PCR lysis reagent (Viagen Biotech, Los Angeles, CA, USA). $M$. incognita was identified to species based on restriction fragment length polymorphism patterns. DNA fragments were amplified by PCR using two primers TRNAH (5'-TGAATTTTTTATTGTGATTAA-3') and MRH106 (5'-AATTTCTAAAGACTTTTCTTAGT-3') (Stanton et al., 1997), digested by the restriction enzyme HinfI (New England BioLabs, Ipswich, MA, USA), and analyzed by gel electrophoresis (Pagan et al., 2015).

Streptomyces saraceticus 31 (SS31) originally isolated from a citrus grove was revitalized and cultured on potato sucrose agar (PSA) plates. Fully grown SS31 was inoculated into sterilized $2 \%$ soybean powder sugar broth, and cultured for 5 days on a shaker set at $130 \mathrm{rpm}$. Culture filtrates containing secondary metabolites were obtained by centrifugation at 10,000 rpm for 1 minute and passing through a $0.22 \mu \mathrm{m}$ Millipore filter. SS31 spores were collected by washing off with $0.5 \%$ Tween 20 from a PSA plate, and the concentration of spores was adjusted to $10^{8}$ $\mathrm{cfu}(\mathrm{OD}=0.3)$. LTM-m was prepared by mixing $40 \% \mathrm{crab}$ shell powder, $30 \%$ soybean powder, $15 \%$ neem seed meal, $10 \%$ sugar, $5 \%$ dolomite, and S. saraceticus SS31.

In vitro antagonistic tests against $\boldsymbol{R}$. solani. In-vitro antagonistic activity against $R$. solani was assayed on a $9-\mathrm{cm}$ dia. PDA plate. A 8-mm paper disc was placed in the center and $R$. solani agar discs $(5 \mathrm{~mm})$ were placed $4 \mathrm{~cm}$ away at each side of the paper disc. For each test, $50 \mu \mathrm{l}$ of SS31 spore suspensions, SS31 culture broths (2\% soybean powder sugar broth), SS31 filtrates, or water (mock control) was placed on the paper disc, and the plates were incubated at $30^{\circ} \mathrm{C}$ until $R$. solani hyphae reached to the edge of the control plate. Percentage of growth inhibition was calculated using the following equation: $(\mathrm{A}-\mathrm{B}) / \mathrm{A} \times 100 \%$, where 
A is the distance between test pathogen and SS31 and B is the radius of the pathogen colony. Each treatment had three replicates and all tests were repeated three times.

In vitro antagonistic tests against $M$. incognita. Egg masses of M. incognita were hatched in water. Secondstaged juvenile $\left(\mathrm{J}_{2}\right)$ was collected, and its concentration was adjusted to $200 \mathrm{~J}_{2} / \mathrm{ml}$. Eggs embedded in a gelatinous matrix were released by adding $10 \%$ commercial bleach, and relocated to fresh water, and the concentration was adjusted to $200 \mathrm{eggs} / \mathrm{ml}$. Approximately $100 \mathrm{~J}_{2}$ or eggs (in $500 \mu \mathrm{l}$ water) were added to a $1.5 \mathrm{ml}$ micro-centrifuge tube and mixed with equal volume of spore suspensions, culture broths or filtrates of SS31 $\left(10^{8} \mathrm{cfu}\right)$. To ensure complete homogeneity, tubes were inverted several times. Percentage of $\mathrm{J}_{2}$ mortality and egg hatching rate were recorded after $24 \mathrm{~h}$ and 5 days of incubation, respectively. Each treatment had three replicates and all tests were repeated three times.

Assays for antagonistic volatiles against $R$. solani. Volatile antimicrobial activity was assayed in a petri dish filling with LTM-m. LTM-m (2, 5, or $10 \mathrm{~g})$ was placed in a petri dish (90 $\mathrm{mm}$ diameter, $20 \mathrm{~mm}$ height), and $10 \mathrm{~g}$ sterilized sand was used as mock controls. A smaller PDA plate (50 $\mathrm{mm}$ diameter) inoculated with a 5-mm $R$. solani hyphae disc was placed on top of LTM-m. The whole set of plates was sealed with parafilm to allow volatile compounds to interact with $R$. solani. $R$. solani culture placing on top of sand was used as a mock control. Plates were kept at room temperature $\left(\sim 25^{\circ} \mathrm{C}\right)$ for 7 days and radial growth of $R$. solani were measured.

Assays for antagonistic volatiles against $M$. incognita. Either egg masses or approximately $100 \mathrm{~J}_{2}$ of $M$. incognita were placed in the center of a $0.08 \%$ water agar plate $(50$ $\mathrm{mm}$ ), which was placed on top of LTM-m or sterilized sand as stated above. After 7 days, percentage of egg hatch and $\mathrm{J}_{2}$ mortality was determined and morphology of eggs and juveniles after treatment were also recorded with an aid of a light microscope.

Growth chamber trials for controlling $R$. solani. $R$. solani inoculum was modified from Yang (1994). R. solani was first grown on sterilized potato cubes for 7 days, and $100 \mathrm{~g}$ of potato were mixed with $900 \mathrm{~g}$ of peat moss (BVB substrates, C100B) to make $R$. solani inoculum. $R$. solani inoculum were then mixed with King root substrates (Dayi, Pingtung County, Taiwan) in a 1:10 ratio to made $R$. solani-infested soils for seedling tray tests. In a clean plastic box, $600 \mathrm{~g}$ of $R$. solani-infested soils and LTM-m (0.08,
0.16 , and $0.24 \%$ ) or $\mathrm{ddH}_{2} \mathrm{O}$ (mock control) were mixed. The mixture was incubated for 14 days in the closed boxes and used as planting materials. A 64 compartment $(8 \times 8)$ seedling tray was filled with planting materials, and two seeds of spoon cabbages (Qing-gang variety) were sown in each hole. The trays were kept in a growth chamber (set at $28^{\circ} \mathrm{C}, 12 \mathrm{~h} / 12 \mathrm{~h}$, light/dark cycle). Emergent percentage of seeds and disease severity were examined 7 and 14 days after sowing. Disease severity was classified using the following scale: 0 , symptomless; 1 , lesions at the base of the stem less than $0.5 \mathrm{~cm} ; 2$, lesion areas between 0.5 and $1 \mathrm{~cm} ; 3$, lesions greater than $1 \mathrm{~cm}$ and showing dampingoff, or post-emergence damping-off; and 4, showing preemergence damping-off.

Growth chamber trials for controlling $M$. incognita. Sand and peat moss after being sterilized were mixed at the ratio of 2:3 (w/w). After adding $M$. incognita eggs (two per $\mathrm{g}$ of soil), soil $(2 \mathrm{~kg})$ were mixed with LTM-m $(0.08,0.16$ or $0.24 \%, w / w)$. Sterilized soil alone was used as a negative control, and soil containing $M$. incognita eggs only was used a positive control. All treatments were individually sealed in a plastic box, kept at $28^{\circ} \mathrm{C}$ for 14 days, and used to grow water spinach (Ipomoea aquatica) in a 3-inch pot (three seeds per pot). Plants were kept in a growth chamber set $28^{\circ} \mathrm{C}$ and $12 \mathrm{~h}$ light $/ 12 \mathrm{~h}$ darkness cycle for 30 days. Number, fresh weight, and height of plants in each pot were recorded. Percentage of root gall formation (Zeck, 1971) and the number of egg mass were also recorded. Each treatment had seven pots, and the experiment was repeated three times.

Greenhouse trials. Trials were conducted in two greenhouses (B02 and K07) located in Yonglin organic farm where plants were infested with RKN. Field infestation rate was evaluated by randomly sampling 100 plants for galling index in a greenhouse. In a $320 \mathrm{~m}^{2}$ greenhouse, $100 \mathrm{~kg}$ of LTM-m containing 1001 of $100 \times$ SS31 culture broths was mixed with soil. Soils were covered with black plastic sheets for 14 days. Water spinach plants $(n=100)$ after growing in soils for 30 days were randomly selected to examine for gall formation and shoot weight. Galling index (0-10) was classified using the following scale: 0 , no galls, $1,1-10 \%$ root system galled; $2,11-20 \%$ galls; $3,21-30 \%$ galls; $4,31-40 \%$ galls; $5,41-50 \%$ galls; $6,51-60 \%$ galls; $7,61-70 \%$ galls; $8,71-80 \%$ galls; $9,81-90 \%$ galls; and $10,91-100 \%$ galls (Zeck, 1971). The experiment was conducted for three successive seasons, from Nov 22, 2019 till May 8,2020 . The dates of harvest were January 17, March 21, and May 8. 
Measurement of soil pH and electrical conductive (EC). Soil samples from greenhouse trials were collected from the rhizosphere of the plants used for disease assessment and analyzed for physical and chemical properties after each of growing seasons. Soil samples were air-dried for one week and passed through a 2-mm diameter test sieve. Soil was mixed with deionized water at a 1:5 (w/v) ratio in a beaker with agitation for $30 \mathrm{~min}$, stood for $10 \mathrm{~min}$, and measured using a FiveEasy pH meter F20 (Mettler Toledo, Columbus, OH, USA) and a EC meter (inoLab Cond 7110, Taiwan).

Soil texture was determined using the Robinson's pipette method (Buchan et al., 1993) with modifications, which clay sedimentation was processed for $7 \mathrm{~h}$, and $25 \mathrm{ml}$ of soil solution was sampled from $7-10 \mathrm{~cm}$ fraction. Sand and clay contents were calculated by the following equations (Gee and Bauber, 1986).

$$
\begin{aligned}
& \text { Sand }(\%)=\frac{\text { Oven }- \text { dried sand weight }}{(1-\text { Soil water content }) \times 50} \times 100 \% \\
& \text { Clay }(\%)=\frac{\text { Oven }- \text { dried clay weight }}{(1-\text { Soil water content }) \times 50} \times 100 \%
\end{aligned}
$$

Soil organic matter (SOM) was determined by mixing $0.5 \mathrm{~g}$ of air-dried soil with $10 \mathrm{ml} 1 \mathrm{~N} \mathrm{~K}_{2} \mathrm{Cr}_{2} \mathrm{O}_{7}$ and $20 \mathrm{ml}$ of sulfuric acid $\left(\mathrm{H}_{2} \mathrm{SO}_{4}\right)$ overnight, and then adding $10 \mathrm{ml}$ phosphoric acid, $50 \mathrm{ml}$ of deionized water and 30 drops of diphenylamine. The resultant solution was tittered to the endpoint with $0.5 \mathrm{~N}$ of $\mathrm{Fe}\left(\mathrm{NH}_{4}\right)_{2}\left(\mathrm{SO}_{4}\right)_{2}$ according to the method described by Nelson and Sommer (1996) and calculated using the following formula.

$$
\begin{aligned}
\operatorname{SOM}(\%)= & 10 \times\left(1-\frac{\text { Sample titer }}{\text { Blank titer }}\right) \times 1 \times \frac{12}{4000} \times 1.3 \\
& \times \frac{100}{0.5} \times 1.724
\end{aligned}
$$

Inorganic $\mathrm{N}$ and $\mathrm{P}$ were quantified followed the methods described by Maynard (1997) and Murphy and Riley
(1962), respectively. The exchangeable $\mathrm{K}, \mathrm{Ca}$, and $\mathrm{Mg}$ ions were quantified following the method of Haby et al. (1990). Exchangeable $\mathrm{K}$ was detected by a Flame photometer (Sherwood 420 Flame photometer, Sherwood Scientific Ltd, Cambridge, UK). Exchangeable $\mathrm{Ca}$ and $\mathrm{Mg}$ were detected by an atomic absorption spectrophotometer (Hitachi, Chiyoda City, Tokyo, Japan).

Statistical analysis. The data of the root galling rate, root galling index, cabbage emergent rate, disease severity, disease incidence and control rate were arcsine transformed, and analyzed using one-way ANOVA followed by least significant difference test in PASW Statistics version 18.0 (SPSS Inc., Chicago, IL, USA). Data of the inhibition rate of SS31 to R. solani, the mortality rate of M. incognita J2 and the egg hatching rate of $M$. incognita were analyzed using one-way ANOVA followed by Tukey's b test.

\section{Results}

Using SS31 against $R$. solani and M. incognita. Antagonistic activities assayed on paper discs revealed that spore suspensions and culture broths of SS31 showed growth inhibitory activities against $R$. solani at rates ranging from $33.2 \%$ to $42.4 \%$ (Table 1 ). SS31 spore suspensions had greater inhibitory effects than culture broths in three different experiments. Growth inhibitory rates of SS31 culture broths decreased slightly after dilution. However, SS31 culture filtrates had no inhibitory effects on $R$. solani.

Mortality assays conducted in a centrifuge tube revealed that $M$. incognita juveniles (J2) remained viable in sterilized distilled water alone (mock control). M. incognita juveniles after being treated with spore suspensions, culture broths, or filtrates of SS31 resulted in a high mortality rate compared to mock controls in all tests (Table 2). The mortality rate of $\mathrm{J} 2$ after treating with SS31 culture broths ranged from $89.3 \%$ to $94.3 \%$. SS31 culture broths resulted

Table 1. Growth inhibitory rates of Rhizoctonia solani treated with spore suspensions or culture broths of SS31

\begin{tabular}{lcccc}
\hline \multirow{2}{*}{ Treatment } & \multicolumn{3}{c}{ Inhibition rate (\%) } \\
\cline { 2 - 5 } & 1st exp. & 2nd exp. & 3rd exp. & Average \\
\hline SS31 spore suspension & $36.4 \pm 0.8 \mathrm{a}^{\mathrm{a}}$ & $43.7 \pm 1.9 \mathrm{a}$ & $47.3 \pm 1.4 \mathrm{a}$ & $42.4 \pm 1.7 \mathrm{a}^{\mathrm{b}}$ \\
SS31 culture broth 30× & $34.7 \pm 1.1 \mathrm{ab}$ & $36.6 \pm 0.7 \mathrm{~b}$ & $41.3 \pm 0.7 \mathrm{a}$ & $37.5 \pm 1.0 \mathrm{ab}$ \\
SS31 culture broth $50 \times$ & $31.9 \pm 0.3 \mathrm{~b}$ & $32.9 \pm 0.3 \mathrm{c}$ & $38.3 \pm 3.7 \mathrm{a}$ & $34.4 \pm 1.5 \mathrm{~b}$ \\
SS31 culture broth $100 \times$ & $27.8 \pm 0.4 \mathrm{c}$ & $31.3 \pm 0.6 \mathrm{c}$ & $40.4 \pm 1.5 \mathrm{a}$ & $33.2 \pm 1.9 \mathrm{~b}$ \\
\hline
\end{tabular}

${ }^{\mathrm{a}}$ Means $(n=3)$ in the same column followed by the same letter are not significantly different $(P=0.05)$ according to Tukey's $\mathrm{b}$ test. Values are presented as mean $\pm \mathrm{SE}$.

${ }^{b}$ Means $(n=9)$ in the same column followed by the same letter are not significantly different $(P=0.05)$ according to Tukey's b test. Values are presented as mean $\pm \mathrm{SE}$. 
Table 2. The mortality of root knot nematode $\mathrm{J}_{2}$ treated with spore suspensions, culture broths or filtrates of SS31

\begin{tabular}{|c|c|c|c|c|c|}
\hline \multirow{2}{*}{ Treatment } & \multicolumn{5}{|c|}{$\mathrm{J}_{2}$ mortality $(\%)^{\mathrm{a}, \mathrm{b}}$} \\
\hline & 1st exp. & 2nd exp. & 3rd exp. & 4th exp. & Average \\
\hline SS31 spore suspension & $68.9 \pm 1.2 \mathrm{~b}^{\mathrm{c}}$ & $65.8 \mathrm{~b} \pm 3.0$ & $74.3 \pm 2.3 \mathrm{ab}$ & $92.1 \pm 3.0 \mathrm{ab}$ & $75.3 \pm 3.2 b c^{d}$ \\
\hline \multicolumn{6}{|l|}{ SS31 culture broth } \\
\hline $30 \times$ & $100 \pm 0 \mathrm{a}$ & $100 \pm 0 \mathrm{a}$ & $81.1 \pm 2.7 \mathrm{ab}$ & $96.3 \pm 1.9 \mathrm{a}$ & $94.3 \pm 2.5 \mathrm{a}$ \\
\hline $50 \times$ & $98.3 \pm 0.3 \mathrm{a}$ & $98.4 \pm 1.6 \mathrm{a}$ & $86.0 \pm 1.8 \mathrm{a}$ & $95.2 \pm 0.6 \mathrm{a}$ & $94.5 \pm 1.6 \mathrm{a}$ \\
\hline $100 \times$ & $94.0 \pm 3.0 \mathrm{a}$ & $97.8 \pm 1.3 \mathrm{a}$ & $75.2 \pm 0.3 \mathrm{ab}$ & $90.3 \pm 2.6 \mathrm{ab}$ & $89.3 \pm 2.7 \mathrm{ab}$ \\
\hline \multicolumn{6}{|l|}{ SS31 filtrate } \\
\hline $30 \times$ & $90.7 \pm 0.8 \mathrm{a}$ & $67.1 \pm 0.6 b$ & $70.1 \pm 2.0 \mathrm{~b}$ & $83.8 \pm 1.3 b$ & $77.9 \pm 3.0 \mathrm{bc}$ \\
\hline $50 \times$ & $92.6 \pm 2.9 \mathrm{a}$ & $66.2 \pm 2.2 \mathrm{~b}$ & $83.4 \pm 4.3 \mathrm{a}$ & $84.6 \pm 3.5 b$ & $81.7 \pm 3.2 \mathrm{abc}$ \\
\hline $100 \times$ & $26.7 \pm 13.1 \mathrm{c}$ & $69.8 \pm 13.1 \mathrm{~b}$ & $80.5 \pm 2.9 \mathrm{ab}$ & $93.9 \pm 1.0 \mathrm{ab}$ & $67.7 \pm 8.6 \mathrm{c}$ \\
\hline
\end{tabular}

${ }^{\mathrm{a}} \mathrm{J}_{2}$ mortality was determined $24 \mathrm{~h}$ after being treated with SS31 culture broth. Each replicate had approximately $100 \mathrm{~J}_{2}$.

${ }^{\mathrm{b}}$ Mortality $=($ number of dead juvenile/total juveniles $) \times 100 \%$. The natural mortality of $\mathrm{J}_{2}$ in the water control after $24 \mathrm{~h}$ in four experiments was zero.

${ }^{c}$ Means $(n=3)$ in the same column followed by the same letter are not significantly different $(P=0.05)$ according to Tukey's b test. Values are presented as mean $\pm \mathrm{SE}$.

${ }^{\mathrm{d}}$ Means $(n=12)$ in the same column followed by the same letter are not significantly different $(P=0.05)$ according to Tukey's $\mathrm{b}$ test. Values are presented as mean $\pm \mathrm{SE}$.

Table 3. The egg hatching rate of root knot nematodes after being treated with culture broths or filtrates of SS31

\begin{tabular}{|c|c|c|c|c|}
\hline \multirow{2}{*}{ Treatment } & \multicolumn{4}{|c|}{ Egg hatching rate $(\%)^{a, b}$} \\
\hline & 1st exp. & 2nd exp. & 3rd exp. & Average \\
\hline SS31 spore suspension & $0.7 \pm 0.7 b^{c}$ & $0.9 \pm 0.5 b$ & $1.8 \pm 0.4 \mathrm{~b}$ & $1.1 \pm 0.3 b^{d}$ \\
\hline \multicolumn{5}{|l|}{ SS31 culture broth } \\
\hline $30 \times$ & $0 \pm 0 \mathrm{~b}$ & $0 \pm 0 \mathrm{~b}$ & $1.0 \pm 0.3 \mathrm{~b}$ & $0.3 \pm 0.2 \mathrm{~b}$ \\
\hline $50 \times$ & $0 \pm 0 \mathrm{~b}$ & $0 \pm 0 \mathrm{~b}$ & $4.4 \pm 1.0 \mathrm{~b}$ & $1.5 \pm 0.8 \mathrm{~b}$ \\
\hline $100 \times$ & $1.1 \pm 0.3 \mathrm{~b}$ & $0.8 \pm 0.8 b$ & $6.1 \pm 1.3 \mathrm{~b}$ & $2.7 \pm 1.0 \mathrm{~b}$ \\
\hline \multicolumn{5}{|l|}{ SS31 filtrate } \\
\hline $30 \times$ & $0.8 \pm 0.8 \mathrm{~b}$ & $0.4 \pm 0.4 \mathrm{~b}$ & $6.8 \pm 3.8 b$ & $2.7 \pm 1.5 \mathrm{~b}$ \\
\hline $50 \times$ & $0 \pm 0 \mathrm{~b}$ & $1.8 \pm 0.7 \mathrm{~b}$ & $11.1 \pm 2.7 \mathrm{~b}$ & $4.3 \pm 0.2 \mathrm{~b}$ \\
\hline $100 \times$ & $0.8 \pm 0.8 \mathrm{~b}$ & $4.8 \pm 0.5 b$ & $9.6 \pm 3.0 \mathrm{~b}$ & $3.6 \pm 1.8 \mathrm{~b}$ \\
\hline Water control & $38.4 \pm 4.8 \mathrm{a}$ & $22.5 \pm 6.7 \mathrm{a}$ & $23.9 \pm 1.3 \mathrm{a}$ & $28.3 \pm 3.5 \mathrm{a}$ \\
\hline
\end{tabular}

${ }^{a}$ Egg hatching rate was determined 5 days after treatment.

${ }^{b}$ Egg hatching rate $=($ the number of juvenile $/($ eggs + juveniles $)) \times 100 \%$.

${ }^{c}$ Means $(n=3)$ in the same column followed by the same letter are not significantly different $(P=0.05)$ according to least significant difference test (LSD). Values are presented as mean \pm SE.

${ }^{\mathrm{d}}$ Means $(n=9)$ in the same column followed by the same letter are not significantly different $(P=0.05)$ according to LSD. Values are presented as mean $\pm \mathrm{SE}$.

in greater mortality than spore suspensions. After 5-day incubation in water, $\sim 28 \%$ of eggs hatched (Table 3). Egg masses incubated in spore suspensions, culture broths, or filtrates resulted in low hatching rates ranging from 0.3 to $4.3 \%$. Egg masses incubated in 30× SS31 culture broths resulted in the lowest hatching rate (average $\sim 0.32 \%$ ).

Volatile compounds of LTM-m. Assays using a petri dish plate inside a bigger plate revealed that growth of $R$. solani upon exposure to LTM-m was inhibited to varying degrees when compared to mock controls (Table 4). $R$. solani never physically contacted with LTM-m, indicating the involvement of toxic volatile compounds that had an inhibitory effect on the growth of $R$. solani. Similar tests were performed using eggs and juveniles of $M$. incognita as targets, revealing that volatile compounds produced from LTM$\mathrm{m}$ significantly inhibited egg hatch and resulted in up to 93.2\% mortality rate of juveniles (Table 5). Untreated nematode eggs showed well-differentiated juveniles inside (Fig. 1A). Many eggs after being exposed to LTM-m failed 
Table 4. The fumigant antagonistic activity of LTM-m against Rhizoctonia solani

\begin{tabular}{lcccc}
\hline & \multicolumn{4}{c}{ Inhibition rate (\%) } \\
\cline { 2 - 5 } Treatment & 1st exp. & 2nd exp. & 3rd exp. & Average \\
\hline LTM-m 2 g & $52 \pm 3.5 \mathrm{a}^{\mathrm{a}}$ & $20.7 \pm 1.8 \mathrm{a}$ & $29 \pm 2.6 \mathrm{a}$ & $33.9 \pm 4.9 \mathrm{a}^{\mathrm{b}}$ \\
LTM-m 5 g & $67 \pm 3.5 \mathrm{a}$ & $29.7 \pm 3.8 \mathrm{a}$ & $14.7 \pm 14.7 \mathrm{a}$ & $37.1 \pm 9.0 \mathrm{a}$ \\
LTM-m 10 g & $50 \pm 14.0 \mathrm{a}$ & $6.0 \pm 4.2 \mathrm{~b}$ & $32 \pm 16.0 \mathrm{a}$ & $29.3 \pm 8.9 \mathrm{a}$ \\
CK $^{\mathrm{c}}$ & $0 \mathrm{~b}$ & $0 \mathrm{~b}$ & $0 \mathrm{a}$ & $0 \mathrm{~b}$ \\
\hline
\end{tabular}

${ }^{a}$ Means $(n=3)$ in the same column followed by the same letter are not significantly different $(P=0.05)$ according to least significant difference test (LSD). Values are presented as mean \pm SE.

${ }^{b}$ Means $(n=9)$ in the same column followed by the same letter are not significantly different $(P=0.05)$ according to LSD. Values are presented as mean $\pm \mathrm{SE}$.

${ }^{\mathrm{c}} \mathrm{CK}: 10 \mathrm{~g}$ sterilized sandy soil with $70 \%$ (v/v) distilled water.

Table 5. The egg hatching rate and the $\mathrm{J}_{2}$ mortality of root knot nematode 7 days after LTM-m fumigation treatment

\begin{tabular}{lcccc}
\hline & \multicolumn{4}{c}{ Egg hatching rate (\%) } \\
\cline { 2 - 5 } Treatment & 1st exp. & 2nd exp. & 3rd exp. & Average \\
\hline Egg hatching rate (\%) & & & & \\
LTM-m 2 g & $8.6 \pm 4.4 \mathrm{~b}^{\mathrm{a}}$ & $11.4 \pm 3.8 \mathrm{~b}$ & $5.2 \pm 1.2 \mathrm{~b}$ & $8.4 \pm 1.9 \mathrm{~b}^{\mathrm{b}}$ \\
LTM-m 5 g & $5.2 \pm 1.4 \mathrm{~b}$ & $10.3 \pm 1.4 \mathrm{~b}$ & $1.8 \pm 0.2 \mathrm{~b}$ & $5.8 \pm 1.4 \mathrm{~b}$ \\
LTM-m 10 g & $2.3 \pm 0.3 \mathrm{~b}$ & $7.2 \pm 1.3 \mathrm{~b}$ & $0.9 \pm 0.4 \mathrm{~b}$ & $3.4 \pm 1.0 \mathrm{~b}$ \\
CK & $47.6 \pm 12.7 \mathrm{a}$ & $78.2 \pm 17.0 \mathrm{a}$ & $74.7 \pm 6.8 \mathrm{a}$ & $66.8 \pm 8.0 \mathrm{a}$ \\
$\mathrm{J}_{2}$ mortality (\%) & & & & \\
LTM-m 2 g & $92.8 \pm 2.3 \mathrm{a}^{\mathrm{c}}$ & $70.7 \pm 13.8 \mathrm{a}$ & $64.7 \pm 7.0 \mathrm{a}$ & \\
LTM-m 5 g & $94.5 \pm 1.7 \mathrm{a}$ & $91.6 \pm 3.2 \mathrm{a}$ & $83.1 \pm 6.7 \mathrm{a}$ & $89.7 \pm 2.8 \mathrm{a}$ \\
LTM-m 10 g & $96.2 \pm 0 \mathrm{a}$ & $90.9 \pm 3.9 \mathrm{a}$ & $92.5 \pm 3.2 \mathrm{a}$ & $93.2 \pm 1.7 \mathrm{a}$ \\
CK & $3.8 \pm 0.3 \mathrm{~b}$ & $3.1 \pm 0.4 \mathrm{~b}$ & $3.4 \pm 1.7 \mathrm{~b}$ & $3.4 \pm 0.5 \mathrm{~b}$ \\
\hline
\end{tabular}

a,c Means $(n=3)$ in the same column followed by the same letter are not significantly different $(P=0.05)$ according to least significant difference test (LSD). Values are presented as mean \pm SE.

${ }^{\mathrm{b}, \mathrm{d}}$ Means $(n=9)$ in the same column followed by the same letter are not significantly different $(P=0.05)$ according to LSD. Values are presented as mean $\pm \mathrm{SE}$.

${ }^{\mathrm{e}} \mathrm{CK}: 10 \mathrm{~g}$ sterilized sandy soil with $70 \%(\mathrm{v} / \mathrm{v})$ distilled water.

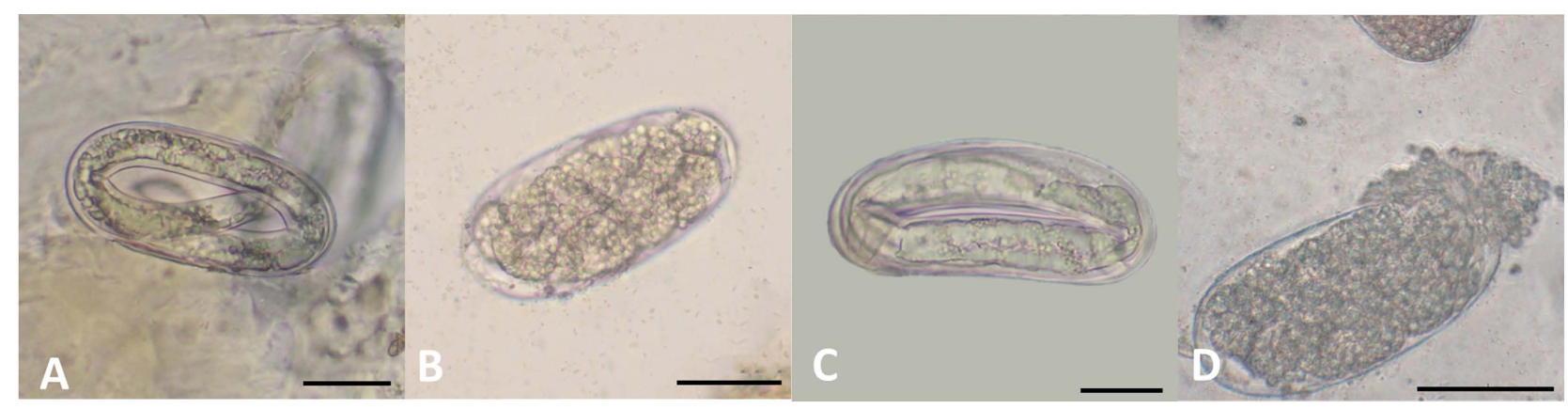

Fig. 1. Morphology of Meloidogyne incognita eggs after LTM-m fumigation treatments for 7 days. (A) Normal unhatched egg without any treatment. (B) Unhatched egg morphology in LTM-m treatments. (C) Deformed juvenile unhatched after $5 \mathrm{~g}$ and $10 \mathrm{~g}$ LTM-m treatment. (D) Lysed egg morphology after $10 \mathrm{~g}$ LTM-m treatment. Scale bars $=10 \mu \mathrm{m}$ (A-C), $20 \mu \mathrm{m}$ (D).

to develop into juveniles and displayed darker color. Some eggs had dense materials inside (Fig. 1B), and others had deformed juveniles (Fig. 1C). Some egg shells were apparently lysed (Fig. 1D).
Disease severity of seedling trays and pot assays. Disease control tests assayed in seedling trays revealed that LTM-m significantly increased the emergent rate of spoon cabbage seeds and decreased $R$. solani-induced seedling 
Table 6. The emergent rate (\%) and disease severity (\%) of spoon cabbage grown in the Rhizoctonia solani-infested planting material with pre-plant amending of different LTM-m concentrations for 14 days

\begin{tabular}{|c|c|c|c|c|c|c|}
\hline \multirow{2}{*}{ Treatment } & \multicolumn{2}{|c|}{ 1st exp. } & \multicolumn{2}{|c|}{ 2nd exp. } & \multicolumn{2}{|c|}{ Average } \\
\hline & Emergent rate & Disease severity & Emergent rate & Disease severity & Emergent rate & Disease severity \\
\hline $\mathrm{CK}^{\mathrm{a}}$ & $43.7 \pm 5.3 b^{b}$ & $66.4 \pm 5.3 \mathrm{a}$ & $58.6 \pm 7.3 b$ & $47.9 \pm 9.8 \mathrm{a}$ & $51.2 \pm 5.0 \mathrm{a}^{\mathrm{c}}$ & $57.1 \pm 6.2 \mathrm{a}$ \\
\hline $0.08 \%$ & $78.1 \pm 3.4 \mathrm{a}$ & $38.5 \pm 2.4 b$ & $84.4 \pm 3.8 \mathrm{a}$ & $24.4 \pm 3.9 \mathrm{a}$ & $58.3 \pm 7.7 \mathrm{a}$ & $31.5 \pm 3.4 b$ \\
\hline $0.16 \%$ & $67.2 \pm 3.7 \mathrm{a}$ & $47.1 \pm 2.2 \mathrm{~b}$ & $61.7 \pm 6.4 b$ & $42.8 \pm 5.4 \mathrm{a}$ & $57.1 \pm 4.3 \mathrm{a}$ & $44.9 \pm 2.8 \mathrm{a}$ \\
\hline $0.24 \%$ & $62.5 \pm 6.9 \mathrm{a}$ & $50.4 \pm 5.4 b$ & $46.9 \pm 10.8 b$ & $54.9 \pm 11.2 \mathrm{a}$ & $56.5 \pm 4.6 \mathrm{a}$ & $52.6 \pm 5.8 \mathrm{a}$ \\
\hline
\end{tabular}

${ }^{a} \mathrm{CK}:$ R. solani-infested soil with $40-50 \%$ (v/v) distilled water.

${ }^{\mathrm{b}}$ Data was presented as means $\pm \mathrm{SE}(n=4)$, means in the same column followed by the same letter are not significantly different $(P=0.05)$ according to least significant difference test (LSD).

${ }^{c}$ Data was presented as means \pm SE $(n=8)$, means in the same column followed by the same letter are not significantly different $(P=0.05)$ according to LSD.

Table 7. The root galling rate (\%), egg mass numbers and the plant height and weight of water spinach planted in RKN-infested soil treated with different concentrations of LTM-m for 14 days before planting

\begin{tabular}{lccrrr}
\hline \multirow{2}{*}{ Treatment } & \multicolumn{2}{c}{ Disease control } & & \multicolumn{2}{c}{ Plant growth } \\
\cline { 2 - 3 } \cline { 5 - 6 } & Galling rate & Egg mass number & & Plant height per pot & Plant weight per pot (g) \\
\hline Blank (water only) & - & - & $37.3 \pm 2.7 \mathrm{a}^{\mathrm{a}}$ & $4.9 \pm 0.6 \mathrm{a}$ \\
CK (nematode only) & $38.3 \pm 6.1 \mathrm{a}^{\mathrm{b}}$ & $21.3 \pm 4.3 \mathrm{a}$ & & $27.8 \pm 1.8 \mathrm{~b}$ & $5.2 \pm 0.6 \mathrm{a}$ \\
$0.08 \%$ & $8.8 \pm 1.8 \mathrm{~b}$ & $5.1 \pm 1.4 \mathrm{~b}$ & & $32.6 \pm 2.0 \mathrm{a}$ & $6.2 \pm 0.8 \mathrm{a}$ \\
$0.16 \%$ & $8.4 \pm 1.6 \mathrm{~b}$ & $4.9 \pm 0.8 \mathrm{~b}$ & & $31.3 \pm 2.2 \mathrm{a}$ & $5.0 \pm 0.7 \mathrm{a}$ \\
$0.24 \%$ & $5.9 \pm 1.3 \mathrm{~b}$ & $3.6 \pm 0.8 \mathrm{~b}$ & & $33.1 \pm 1.9 \mathrm{a}$ & $6.1 \pm 0.8 \mathrm{a}$ \\
\hline
\end{tabular}

RKN, root knot nematode.

${ }^{\mathrm{a}, \mathrm{b}}$ Data was presented as means $\pm \mathrm{SE}(n=21)$, means in the same column followed by the same letter are not significantly different $(P=0.05)$ according to least significant difference test.

damping-off (Table 6). Pot assays revealed that nearly $38 \%$ of water spinach roots grown in $\mathrm{RKN}$-infested soil bore galls 30 days after planting (Table 7). The number of egg masses was estimated to be around 21.3 per pot. Plants grown in soil mixing with LTM-m decreased the rate of gall formation as low as $5.9 \%$. Increasing the amount of LTM-m decreased the rate of gall formation and the number of egg masses. The number of egg masses was significantly reduced in soil mixing with LTM-m. No galls or egg masses were found in plants grown in control soil. Plants grown in soil containing LTM-m were significantly higher than those grown in soil without LTM-m. However, plant weights showed no significant differences among all treatments.

Disease severity and plant yield after LTM-m application in greenhouses. Field sampling of water spinach over four successive seasons in two greenhouses (B02 and K07) revealed that application of LTM-m significantly reduced the formation of root knots, particularly in greenhouse B02 (Fig. 2). In greenhouse B02, galling index increased from 0.84 to 2.05 after the first growing season. LTM-m

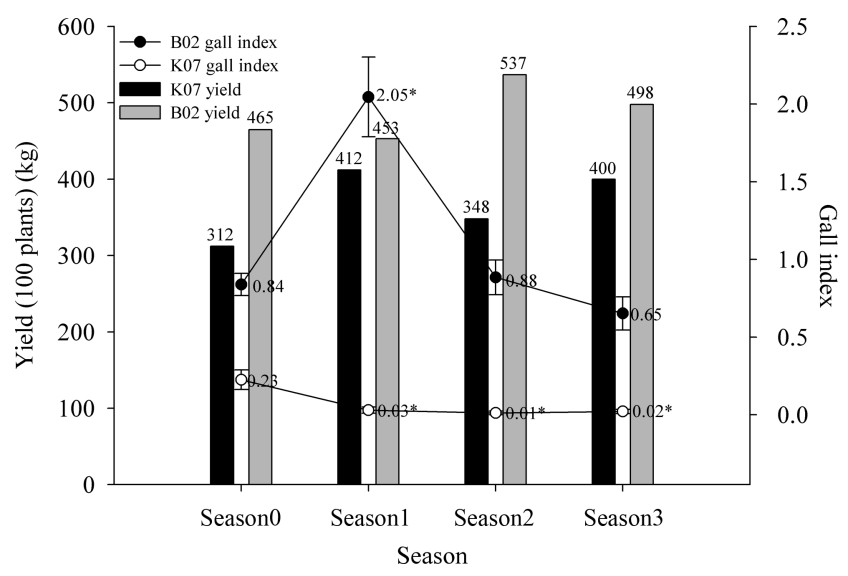

Fig. 2. The root knot galling index and the yield (100 plants) of water spinach with three successive LTM-m pre-plant treatments. The galling index was classified into 11 grades, where $0=$ no galls, and every $10 \%$ was classified as one grade till $10=91$ $100 \%$ roots galled.

was added into soil at the beginning of the second growing season, and galling index decreased considerably (decreasing from 2.05 to 0.88 ) as assayed at the end of the second growing season. Application of LTM-m at the beginning 
Table 8. The soil properties in two greenhouse trails with three successive LTM-m pre-plant treatments

\begin{tabular}{|c|c|c|c|c|c|c|c|c|c|c|c|c|c|}
\hline \multirow[b]{2}{*}{$\mathrm{GH}^{\mathrm{a}}$} & \multirow{2}{*}{$\begin{array}{l}\text { Date } \\
(2020)\end{array}$} & \multirow{2}{*}{$\begin{array}{c}\mathrm{pH} \\
(1: 5)\end{array}$} & \multirow{2}{*}{$\begin{array}{c}\text { EC } \\
(1: 5) \\
(\mathrm{dS} / \mathrm{m})\end{array}$} & \multirow{2}{*}{$\begin{array}{l}\mathrm{OM} \\
(\%)\end{array}$} & \multicolumn{5}{|c|}{ Content (mg/kg soil) } & \multicolumn{4}{|c|}{ Soil texture } \\
\hline & & & & & $\begin{array}{l}\text { Inorg } \\
\text { anic-N }\end{array}$ & Bray-1 P & Ex-K & $\mathrm{Ex}-\mathrm{Ca}$ & Ex-Mg & $\begin{array}{l}\text { Sand } \\
(\%)\end{array}$ & $\begin{array}{l}\text { Silt } \\
(\%)\end{array}$ & $\begin{array}{l}\text { Clay } \\
(\%)\end{array}$ & Texture \\
\hline \multirow[t]{3}{*}{ B02 } & $01 / 17$ & $7.1 \mathrm{a}^{\mathrm{b}}$ & $0.2 \mathrm{a}$ & $3.4 \mathrm{~b}$ & $11.3 \mathrm{a}$ & $208.0 \mathrm{c}$ & $187.3 \mathrm{a}$ & $1,850.4 \mathrm{a}$ & $470.2 \mathrm{a}$ & 39 & 60.1 & 0.9 & Silt loam \\
\hline & $03 / 21$ & $7.2 \mathrm{a}$ & $0.1 \mathrm{~b}$ & $3.6 \mathrm{~b}$ & $1.1 \mathrm{~b}$ & $218.2 \mathrm{~b}$ & $183.4 \mathrm{ab}$ & $1,289.8 \mathrm{~b}$ & $271.9 \mathrm{~b}$ & & & & \\
\hline & $05 / 08$ & $7.3 \mathrm{a}$ & $0.04 \mathrm{c}$ & $4.2 \mathrm{a}$ & $5.6 \mathrm{ab}$ & $282.0 \mathrm{a}$ & $176.0 \mathrm{~b}$ & $895.6 \mathrm{~b}$ & $221.8 \mathrm{~b}$ & & & & \\
\hline \multirow[t]{3}{*}{ K07 } & $01 / 17$ & $7.0 \mathrm{~b}$ & $0.3 \mathrm{~b}$ & $2.3 \mathrm{a}$ & $9.0 \mathrm{~b}$ & $64.0 \mathrm{a}$ & $169.4 \mathrm{a}$ & $1905.0 \mathrm{a}$ & $402.5 \mathrm{a}$ & 36 & 63 & 1 & Silt loam \\
\hline & $03 / 21$ & $7.0 \mathrm{~b}$ & $0.5 \mathrm{a}$ & $2.4 \mathrm{a}$ & $16.9 \mathrm{a}$ & $62.0 \mathrm{a}$ & $120.7 \mathrm{~b}$ & $983.8 \mathrm{~b}$ & $182.3 \mathrm{~b}$ & & & & \\
\hline & $05 / 08$ & $7.4 \mathrm{a}$ & $0.2 \mathrm{c}$ & $2.4 \mathrm{a}$ & $5.6 \mathrm{~b}$ & $60.5 \mathrm{a}$ & $116.1 \mathrm{~b}$ & $895.6 \mathrm{~b}$ & $157.5 \mathrm{~b}$ & & & & \\
\hline
\end{tabular}

${ }^{\mathrm{a}} \mathrm{GH}$, greenhouse code; $\mathrm{pH}(1: 5)$, the soil $\mathrm{pH}$ value was tested by adding $1 \mathrm{~g}$ soil in $5 \mathrm{ml}$ water; EC (1:5), the soil electrical conductivity was tested with $1 \mathrm{~g}$ soil in $5 \mathrm{ml}$ water; OM, organic matter; Bray-1 P, inorganic phosphorus; $\mathrm{EX}-\mathrm{K}, \mathrm{Ca}, \mathrm{Mg}$, exchangeable cation of $\mathrm{K}$, Ca, Mg.

${ }^{b}$ Means $(n=3)$ in the same column followed by the same letter are not significantly different $(P=0.05)$ according to Tukey's $\mathrm{b}$ test.

of the third season resulted in further reduction in galling index. Although galling index was much lower in greenhouse K07, it appeared that application of LTM-m also significantly reduced galling index as assayed from samples collected from successive growing seasons. Application of LTM-m increased biomass yields of water spinach shoots in three growing seasons compared to those of the first season.

Soil physical and chemical properties after successive LTM-m applications. The type of soil texture in both greenhouses is silt loam. Soil $\mathrm{pH}$ values increased, and EC values decreased after LTM-m treatment (Table 8). SOM increased after LTM-m treatment in greenhouse B02, whereas no significant changes of organic matter were observed in greenhouse K07. The content of soil inorganic nitrogen fluctuated between growing seasons, showing no significant difference between growing seasons with and without LTM-m treatment. The content of soil inorganic phosphorus increased in greenhouse B02 after LTM-m treatment. In greenhouse $\mathrm{K} 07$, the content of inorganic phosphorus had no significant difference in soil with or without LTM-m treatment after three growing seasons. The value of exchangeable cations $\mathrm{K}, \mathrm{Mg}$ and $\mathrm{Ca}$ decreased in both greenhouses (Table 8).

\section{Discussion}

In this present study, we have demonstrated that the SS31 isolate of $S$. saraceticus applied as soil amendments could reduce soil-borne pathogens and increase plant yields. This study points to the notion that SS31 with great potential on biological control could be suitable for organic farming system. As assayed on plates, the results clearly showed that SS31 spore suspensions resulted in the best inhibitory efficacy against $R$. solani. Surprisingly, SS31 broth filtrates, from which $S$. saraceticus biomases were removed, had no inhibitory activity, indicating the vital requirements of SS31 spores for a successful disease management. The results also suggested that secondary metabolites produced by SS31 for 5 days in the culture broth might not be sufficient to suppress the growth of $R$. solani. It is also possible that antifungal substances are not secreted into medium. Dual culture assays revealed that $R$. solani hyphae cocultured with SS31 spore suspensions or culture broth (containing SS31 spores) showed necrosis, indicating a fungicidal activity of SS31 spore suspensions that could be diffused into the PSA plates. SS31 bioactivities against RKN revealed further that culture broths or filtrates of SS31 effectively killed RKN J2 and suppressed egg hatching. A large amount of unhatched eggs was observed to contain condensed protoplasm. Similar results have been reported in Heterodera glycines after being treated with geldanamycin (at $10 \mu \mathrm{g} / \mathrm{ml}$ ) produced by Streptomyces hygroscopicus (Skantar et al., 2005). This supports further the notion that SS31 after culturing in soybean powder and sugar-containing broth might be able to produce toxic compounds to inhibit $M$. incognita.

In addition to culture broths and spore suspensions, the results of two-plate assays also indicated that LTM-m emitted volatile compounds that are toxic to $R$. solani and $M$. incognita. The fumigants released by LTM-m effectively inhibited hyphal growth of $R$. solani and RKN egg hatching, and even caused the death of RKN juveniles. Statistics showed that LTM-m applied at $5 \mathrm{~g}$ per plate had the best inhibitory effect on the growth of $R$. solani. However, some discrepancies, which could likely due to an incomplete mixing of LTM-m ingredients, were observed among different treatments and experiments. Nevertheless, all LTM$\mathrm{m}$ treatments had inhibitory effects compared to the control 
treatment. For assays using RKN as a target, $10 \mathrm{~g}$ of LTM$\mathrm{m}$ resulted in the highest $\mathrm{J}_{2}$ mortality and inhibition of egg hatching. Many eggs treated by LTM-m volatile compounds failed to hatch, became lysed or had deformed juveniles, suggesting that the toxic substances could dissolve in soft water agar, in which RKN juveniles and eggs were embedded. The results strongly suggested that amending LTM-m before planting in the fields for appropriate length could suppress the population of $R$. solani and RKN.

LTM-m contains organic ingredients, which are easily accessible and eco-friendly. A combination of those natural materials with $S$. saraceticus SS31 apparently can mitigate soil-borne diseases. Crab and shrimp shell powder, which contains abundant of chitin, has been proven to enhance the population of Streptomyces spp. in soil (Mitchell and Alexander, 1962; Sneh et al., 1971; Williams and Robinson, 1981). Soybean meal can release $\mathrm{NH}_{3}$ during decomposition, and $\mathrm{NH}_{3}$ can also inhibit soil-borne pathogens and nematodes (van Bniggen and Termorskuizen, 2003). Dolomite is well-known for soil acidity improvement, and its high magnesium content and high soil $\mathrm{pH}$ value have been known for the better soil suppressiveness (Wang and Hsieh, 1986; Young et al., 1991). High soil pH could hydrolyze more urea and keep more nitrogen in soil, both of which can lead to a better suppression to diseases and pathogens (Zasada and Tenuta, 2008). In this study, a combination of organic soil amendment and Streptomyces saraceticus SS31 has been demonstrated to suppress two economically important pathogens. Seedling tray tests showed that $0.08 \%$ LTM-m pre-planting treatment could achieve the best results on the promotion of seed germination and the suppression of disease severity caused by $R$. solani. Pot experiments showed that all LTM-m, particularly at $0.24 \%$, pre-planting treatments successfully decreased the galling rate and egg mass number of $M$. incognita on the roots of water spinach. In M. incognita-infested soil, application of LTM-m at $0.08 \%$ and $0.24 \%$ slightly but not significantly increased plant weight compared to the control treatment. It appears that application of $0.08 \%$ LTM-m is sufficient to decrease the damages caused by RKN and increase shoot weight.

Soil suppressiveness to plant pathogens are closely influenced by soil microorganisms, soil fertility, and soil properties. Soil amendments have been shown to improve soil aeration, soil structure, drainage, moisture holding capacity, nutrient availability, and microbial ecology (Bailey and Lazarovits, 2003). Due to those improvements, soil amendments have been demonstrated to alleviate a number of plant diseases (Abawi and Widmer, 2000; Akhtar and Malik, 2000; Bonanomi et al., 2007; Conn and Lazarovits,
2000; Cook, 1986; Gamliel et al., 2000; Lazarovits et al., 2001). In greenhouse studies, our results have shown that three successive pre-planting applications of LTM-m significantly reduced root galling index and increased plant fresh weight, indicating the practical application of LTM$m$ under the field conditions.

Application of LTM-m increased the $\mathrm{pH}$ value in both greenhouses, likely due to the presence of dolomite in LTM-m. Soil pH could greatly influence the availability of nutrients (McCauley et al., 2009) because some nutrients exist in different forms under different $\mathrm{pH}$ values, and not all the forms could be taken up by plants. Studies have shown that a prolonged application of organic fertilizer will increase soil $\mathrm{pH}$ values to neutral or slightly alkaline (Fließbach et al., 2007). Under the alkaline conditions, $\mathrm{NH}_{4}$ and $\mathrm{OH}^{-}$could generate ammonia, which may cause low soil fertility and prevent plant growth (Zhu et al., 2011). Thus, increasing soil $\mathrm{pH}$ after LTM-m application may benefit the growth of water spinach.

Although soil EC values slightly decreased after LTM$\mathrm{m}$ treatment in two greenhouses, the changes were insignificant. It has been long known that the EC value of soil saturated solution, if higher than $4 \mathrm{dS} / \mathrm{m}$, may cause salt accumulation, which could inhibit plant growth (Shahid and Rahman, 2011). SOM, which is relevant to soil fertility and yields is also an important factor for soil quality (Reeves, 1997). After applying LTM-m, SOM in both greenhouses increased, which might have an effect on the increase of plant fresh weight.

The amount of inorganic nitrogen decreased after LTM$m$ treatment. The amount of inorganic nitrogen can be affected by many factors, including mineralization, nitrogen fixation, nitrification, leaching and plant assimilation, etc. (Nguyen et al., 2017). Organic amendments provide not only nutrients to plants, but also enrich the population of microorganisms in the soil, and increasing soil microorganisms might lower soil inorganic nitrogen due to better mineralization. Because the texture of soil in our test sites is silt loam, it might be prone to a leaching effect (de Vos et al., 2000) and lower inorganic nitrogen in the soil. Soil $\mathrm{pH}$ value and properties could affect the available phosphorus concentration (Larsen, 1967), which might explain why soil inorganic phosphorus increased in greenhouse B02 and no significant changes in greenhouse K07. It is noticeable that the amount of soil $\mathrm{Ca}, \mathrm{Mg}$ or $\mathrm{K}$, which is antagonistic to each other decreased after LTM-m application in both greenhouses. The $\mathrm{Ca} / \mathrm{Mg}$ ratio in greenhouse B02 is between 3 and 4, which is an ideal ratio for plants as proposed by (Kopittke and Menzies, 2007). In contrast, the $\mathrm{Ca} / \mathrm{Mg}$ ratio in greenhouse $\mathrm{K} 07$ is around 5.75, which 
might decrease the availability of $\mathrm{Mg}$ to plants. High $\mathrm{Ca}$ concentration might lead to low availability of phosphorus as observed in the greenhouse $\mathrm{K} 07$.

In this study, LTM-m containing S. saraceticus SS31 was formulated as an organic soil amendment and tested for its efficacy for controlling Rhizoctonia blight and RKN in both laboratory and greenhouse conditions. Application of LTM-m could also reduce the outbreak of downy mildew in two greenhouse trails on Chinese kale and the hybrid of bok choy and spoon cabbage (data not shown). This warrants further investigation in the future. Preliminary tests in the lab also revealed that volatile compounds emitted from LTM-m had growth inhibitory against Sclerotinia sclerotiorum and Botrytis sp. (data not shown), suggesting a broad spectrum of volatile compounds against plant pathogens. Overall, our studies indicate that improving LTM-m efficacy by integrating it with other cultural practices shall offer more control strategies to organic farming system.

\section{Conflicts of Interest}

No potential conflict of interest relevant to this article was reported.

\section{Acknowledgments}

We would like to thank Dr. Kuang-Ren Chung for his editorial suggestions, and Dr. Hung-Yu Lai kindly let us using the soil property analysis apparatuses. The research is partially supported by Bureau of Animal and Plant Health Inspection and Quarantine, Council of Agriculture, Executive Yuan, Project 109A164.

\section{References}

Abawi, G. S. and Widmer, T. L. 2000. Impact of soil health management practices on soilborne pathogens, nematodes and root diseases of vegetable crops. Appl. Soil Ecol. 15:37-47.

Akhtar, M. and Malik, A. 2000. Roles of organic soil amendments and soil organisms in the biological control of plantparasitic nematodes: a review. Bioresour. Technol. 74:35-47.

Al-Barakah, F. N., Radwan, S. M. A. and Abdel-Aziz, R. A. 2013. Using biotechnology in recycling agricultural waste for sustainable agriculture and environmental protection. Int. J. Curr. Microbiol. Appl. Sci. 2:446-459.

Al-Fadhal, F. A., Al-Abedy, A. N. and Al-Janabi, M. M. 2018. Molecular identification of novel isolates of Rhizoctonia solani Kühn and Fusarium spp. (Matsushima) isolated from petunia plants (Petunia hybrida L.). Plant Arch. 18:703-711.

Bailey, K. L. and Lazarovits, G. 2003. Suppressing soil-borne diseases with residue management and organic amendments. Soil Tillage Res. 72:169-180.

Bonanomi, G., Antignani, V., Pane, C. and Scala, F. 2007. Suppression of soilborne fungal diseases with organic amendments. J. Plant Pathol. 89:311-324.

Buchan, G. D., Grewal, K. S., Claydon, J. J. and Mcpherson, R. J. 1993. A comparison of sedigraph and pipette methods for soil particle-size analysis. Australas. J. Soil Res. 31:407-417.

Chen, Y.-C. 2008. Application of Streptomyces spp. for controlling disease caused by plant pathogenic fungi and plant parasitic nematodes. M.S. thesis. National Chung Hshing University, Taichung, Taiwan (in Chinese).

Conn, K. L. and Lazarovits, G. 2000. Soil factors influencing the efficacy of liquid swine manure added to soil to kill Verticillium dahliae. Can. J. Plant Pathol. 22:400-406.

Cook, R. J. 1986. Plant health and the sustainability of agriculture, with special reference to disease control by beneficial microorganisms. Biol. Agric. Hortic. 3:211-232.

Damm, U., Sato, T., Alizadeh, A., Groenewald, J. Z. and Crous, P. W. 2019. The Colletotrichum dracaenophilum, C. magnum and C. orchidearum species complexes. Stud. Mycol. 92:146.

de Vos, J. A., Hesterberg, D. and Raats, P. A. C. 2000. Nitrate leaching in a tile-drained silt loam soil. Soil Sci. Soc. Am. J. 64:517-527.

Fließbach, A., Oberholzer, H.-R., Gunst, L. and Mäder, P. 2007. Soil organic matter and biological soil quality indicators after 21 years of organic and conventional farming. Agric. Ecosyst. Environ. 118:273-284.

Gamliel, A., Austerweil, M. and Kritzman, G. 2000. Non-chemical approach to soilborne pest management: organic amendments. Crop Prot. 19:847-853.

Gee, G. W. and Bauder, J. W. 1986. Particle size analysis. In: Methods of soil analysis, Part 1. 2nd ed., Vol. 9, ed. by A., Klute, pp. 383-411. The American Society of Agronomy, Soil Science Society of America, Madison, WI, USA.

Goyal, S., Chander, K., Mundra, M. C. and Kapoor, K. K. 1999. Influence of inorganic fertilizers and organic amendments on soil organic matter and soil microbial properties under tropical conditions. Biol. Fertil. Soils 29:196-200.

Haby, V. A., Russelle, M. P. and Skogley, E. O. 1990. Testing soils for potassium, calcium, and magnesium. In: Soil testing and plant analysis, 3rd ed. Vol. 3, ed. by R. L. Westerman, pp. 181-227. The Soil Science Society of America, Inc., Madison, WI, USA.

Huang, C. Y. 2016. Studies on the potency of applying two species of Streptomyces with chemicals to control Meloidogyne incognita and Xanthomonas vesicatoria. M.S. thesis. National Chung Hshing University, Taichung, Taiwan (in Chinese).

Huang, L.-F., Song, L.-X., Xia, X.-J., Mao, W.-H., Shi, K., Zhou, Y.-H. and Yu, J.-Q. 2013. Plant-soil feedbacks and soil sickness: from mechanisms to application in agriculture. J. Chem. Ecol. 39:232-242.

Hussey, R. S. 1973. A comparison of methods of collecting inocula of Meloidogyne spp., including a new technique. Plant 
Dis. Rep. 57:1025-1028.

Kopittke, P. M. and Menzies, N. W. 2007. A review of the use of the basic cation saturation ratio and the "ideal" soil. Soil Sci. Soc. Am. J. 71:259-265.

Larsen, S. 1967. Soil phosphorus. Adv. Agron. 19:151-210.

Lazarovits, G., Tenuta, M. and Conn, K. L. 2001. Organic amendments as a disease control strategy for soilborne diseases of high-value agricultural crops. Australas. Plant Pathol. 30:111-117.

Maynard, D. G. 1997. Soil nutrient dynamics in a boreal mixedwood cutover following the application of hexazinone. Ecol. Appl. 7:416-430.

McCauley, A., Jones, C. and Jacobsen, J. 2009. Soil pH and organic matter. Nutr. Manag. Modul. 8:1-12.

Mitchell, R. and Alexander, M. 1962. Microbiological processes associated with the use of chitin for biological control. Soil Sci. Soc. Am. J. 26:556-558.

Murphy, J. and Riley, J. P. 1962. A modified single solution method for the determination of phosphate in natural waters. Anal. Chim. Acta 27:31-36.

Nelson, D. W. and Sommers, L. E. 1996. Total carbon, organic carbon, and organic matter. In: Methods of soil analysis: part 3 chemical methods, 5.3, eds. by D. L. Sparks, A. L. Page, P. A. Helmke, R. H. Loeppert, P. N. Soltanpour, M. A. Tabatabai, C. T. Johnston and M. E. Sumner, pp. 961-1010. The Soil Science Society of America, Inc., Madison, WI, USA.

Nguyen, T. T. N., Xu, C.-Y., Tahmasbian, I., Che, R., Xu, Z., Zhou, X., Wallace, H. M. and Bai, S. H. 2017. Effects of biochar on soil available inorganic nitrogen: a review and metaanalysis. Geoderma 288:79-96.

Oka, Y. 2010. Mechanisms of nematode suppression by organic soil amendments: a review. Appl. Soil Ecol. 44:101-115.

Pagan, C., Coyne, D., Carneiro, R., Kariuki, G., Luambano, N., Affokpon, A. and Williamson, V. M. 2015. Mitochondrial haplotype-based identification of ethanol-preserved root-knot nematodes from Africa. Phytopathology 105:350-357.

Prabavathy, V. R., Mathivanan, N. and Murugesan, K. 2006. Control of blast and sheath blight diseases of rice using antifungal metabolites produced by Streptomyces sp. PM5. Biol. Control 39:313-319.

Reeves, D. W. 1997. The role of soil organic matter in maintaining soil quality in continuous cropping systems. Soil Tillage Res. 43:131-167.

Shahid, S. A. and Rahman, K. 2011. Soil salinity development, classification, assessment, and management in irrigated agriculture. In: Handbook of plant and crop stress, 3rd ed., ed. by M. Pessarakli, pp. 23-39. CRC Press, Boca Raton, FL, USA.

Sikora, R. A. and Roberts, P. A. 2018. Management practices: an overview of integrated nematode management technologies. In: Plant parasitic nematodes in subtropical and tropical agriculture, 3rd ed., eds. by R. A. Sikora, D. Coyne, J. Hallmann and P. Timper, pp. 795-838. CAB International, Wallingford, Oxfordshire, UK.

Skantar, A. M., Agama, K., Meyer, S. L. F., Carta, L. K. and Vinyard, B. T. 2005. Effects of geldanamycin on hatching and juvenile motility in Caenorhabditis elegans and Heterodera glycines. J. Chem. Ecol. 31:2481-2491.

Sneh, B., Katan, J. and Henis, Y. 1971. Mode of inhibition of Rhizoctonia solani in chitin-amended soil. Phytopathology 61:1113-1117.

Stanton, J., Hugall, A. and Moritz, C. 1997. Nucleotide polymorphisms and an improved PCR-based mtDNA diagnostic for parthenogenetic root-knot nematodes (Meloidogyne spp.). Fundam. Appl. Nematol. 20:261-268.

Sutherland, E. D. and Papavizas, G. C. 1991. Evaluation of oospore hyperparasites for the control of phytophthora crown rot of pepper. J. Phytopathol. 131:33-39.

Tang-um, J. and Niamsup, H. 2012. Chitinase production and antifungal potential of endophytic Streptomyces strain P4. Maejo Int. J. Sci. Technol. 6:95-104.

Tu, K.-I. 2014. Using Streptomyces spp. for promoting plant growth and investigating their root growth regulators. M.S. thesis, National Chung Hshing University, Taichung, Taiwan (in Chinese).

van Bniggen, A. H. C. and Termorskuizen, A. J. 2003. Integrated approaches to root disease management in organic farming systems. Integrated approaches to root disease management in organic farming systems. Australas. Plant Pathol. 32:141156.

van den Ende, A. H. G. G. and de Hoog, G. S. 1999. Variability and molecular diagnostics of the neurotropic species Cladophialophora bantiana. Stud. Mycol. 43:151-162.

Wang, J. F. and Hsieh, W. H. 1986. Studies on the suppressive factors and characteristics of suppressive soils of clubroot in crucifers. Plant Prot. Bull. 28:363-370.

Williams, S. T. and Robinson, C. S. 1981. The role of streptomycetes in decomposition of chitin in acidic soils. J. Gen. Microbiol. 127:55-63.

Yang, S.-H. 1994. Control of Rhizoctonia damping-off of garden peas. M.S. thesis, National Chung Hshing University, Taichung, Taiwan (in Chinese).

Young, C. C., Cheng, K. T. and Waller, G. R. 1991. Phenolic compounds in conducive and suppressive soils on clubroot disease of crucifers. Soil Biol. Biochem. 23:1183-1189.

Zasada, I. A. and Tenuta, M. 2008. Alteration of the soil environment to maximize Meloidogyne incognita suppression by an alkaline-stabilized biosolid amendment. Appl. Soil Ecol. 40:309-317.

Zeck, W. M. 1971. A. rating scheme for field evaluation of rootknot nematode infestations. Pflanzenschutz Nachrichten Bayer 24:141-144.

Zhu, T., Zhang, J. and Cai, Z. 2011. The contribution of nitrogen transformation processes to total $\mathrm{N}_{2} \mathrm{O}$ emissions from soils used for intensive vegetable cultivation. Plant Soil 343:313327.

Zuberer, D. A., Kenerley, C. M. and Jeger, M. J. 1988. Populations of bacteria and actinomycetes associated with sclerotia of Phymatotrichum omnivorum buried in Houston black clay. Plant Soil 112:69-76. 